\title{
Key Determinants of Service Quality and Self-Service Technologies in Iranian Banking
}

\author{
Hossein Vazifehdoost ${ }^{1}$, Zohreh Akbarpour ${ }^{1}$, Jamshid Mohammadzadeh Rostami ${ }^{1} \&$ Karim Hamdi $^{1}$ \\ ${ }^{1}$ Department of Business Management, Science and Research Branch, Islamic Azad University, Tehran, Iran \\ Correspondence: Zohreh Akbarpour, School of Management and Economics, Islamic Azad University (Tehran \\ Science and Research branch), Tehran, Iran. E-mail: zohreh.akbarpour@gmail.com
}

\author{
Received: July 5, $2013 \quad$ Accepted: July 18, $2013 \quad$ Online Published: November 7, 2013 \\ doi:10.5539/ijms.v5n6p133 URL: http://dx.doi.org/10.5539/ijms.v5n6p133
}

\begin{abstract}
The objective of the current research is investigating the effects of service quality dimensions and self-service technologies on customer satisfaction of the private banking industry of Iran (Ghavamin Bank).Applied method has been used for this research in which the questionnaire method has been utilized in order to gather the required data for describing the research variables and interpreting the relations between them. The Analysis unit in this research is the banking services customers for which 510 people have answered the questionnaires. In order to describe the data, the frequency distribution tables have been used and the structural equations model has been used to describe the data. In so doing, SPSS 18.0 \& LISREL 8.54 softwares have been utilized the explanatory factor analysis, confirmatory factor analysis, path analysis, fitting testingin, and model power analysis methods. The results gained due to this research indicate that three factors assurance and responsiveness and tangible physical factors have got direct relations with the customers' satisfaction. Statistically, two factors i.e. reliability and empathy have no meaningful impact on the customers' satisfaction and cannot function as appropriate indexes for predicting the customers satisfaction from the services provided by the bank. Ultimately, the more satisfactory the self-service technologies factors in the bank branches, the more the extensiveness of physical and tangible factors on the customers' satisfaction shall be. Accordingly, the self-service technologies shall positively adjust the physical \& tangible effects of the customers' satisfaction.
\end{abstract}

Keywords: customer services quality, customer satisfaction, self-service technologies, banking, Iran

\section{Introduction}

The global increasing economic and commercial developments and the function complexities of various economic systems acting nationally, regionally and the like has cause common and interrelated systems come into existence.

In today's changing environment, in order to continue to exist, corporations should adjust themselves with changes and show more flexibility.

Developing an appropriate structure is an integrated feature of the current communities and in the current century's competitive world, the corporations shall be successful that in terms of the activities are a step ahead of their rivals (Johns \& Perrot, 2008; Sangeetha \& Mahalingam, 2011).

Nowadays, people live in an environment which is increasingly moved towards an economy based on services. Service is no more considered a small part of economy, yet it is considered as a value generating heart in economy. Nowadays, Service is not restricted to banking, postal, insurance, health or educational services; most of the products one purchases also include some elements of service as well. In the recent years, the increasing growth of service has been turned into one of the major trends in the world. The replacement and change in the economy which has been based on service, has been totally revealed since 1970 (Schneider and White, 2004).

Today, the service quality issue is considered a global commerce having a commercial value and has got approximately 20 percent of the global commerce. The service sector is one of the principal sectors in every country. The developed countries of the world have now realized the increasing importance of service as the growth and improvement potential upon achieving the industry and mines as well as agriculture powers. The fundamental point is that in the culture of all communities, the role and function of customer should be correctly defined and explained and serving the customer should be introduced as a value and to be practiced so that 
organizations are placed in their proper directions. As a result, this will trigger more satisfaction and loyalty of the customer (Jamal \& Anastasiadou, 2009; Kassim \& Abdullah, 2010; Tsoukatos \& Mastrojianni, 2010).

As of 1960 onwards, the banking services have been greatly changed. After 1980, upon the entering of computers into banking services, the domains of such services have expanded more. Hence, in line with improving the self-services methods, the banks of the world considered the move towards the modern banking, supplying more services via self-service technologies (ATMs, Internet banking, Mobile banking and telephone banking) in their future planning (Ganguli \& Roy, 2010, 2011; Nilsson, 2007; Proenca \& Rodrigues, 2011; Santouridis \& Trivellas, 2010; Wessels \& Drennan, 2010).

In line with the changes, the customers' expectations from the banking network has grown to the extent that all customers expect high quality services, increase in conducting every and each banking transaction as well as the special attention of the staff. By using the internet networks, the speed in rendering service has automatically improved; however, by enhancing the machine performance and technology progress, accuracy and precision is not achieved. That is why the improvement in providing quality banking services is supported as a culture throughout the banking system of the leading banks. In all successful banks of the world, the long-term and principal priority is considering the customer as their main business priority. The Iranian banks are not an exception since in their effort for increasing their shares out of the banking services market, only the bank shall be more successful that considers the banking services quality improvement a strategy and not a tactical plan. Therefore, using an analysis, we spot the factors effective in non upgrading the banking services quality in Iran and we suggest solutions and apply them. With regard to the concept of customer satisfaction and customer care in the current situations and ignoring the human values and considering the efforts of the staff in an organization, in addition to explaining the combined model of servqual and counting the effective factors on services quality, this research is conducted to focus on the human values and capacities in providing more and better services. In Iran, despite the increasing importance of the service sector in the national economy, this sector has been neglected and in the management related literatures, it has not been dealt with as it should have been. So in reply to this failure, it is tried in this research to explain the foundations of the service quality particularly in banking and to answer the major question in this field which is "How a service quality model tailored to the customers' expectations in the target bank of this study could be devised and implemented?". In the second chapter the theoretical issues, the related literature, conceptual model and the research hypotheses will be dealt with. In the third chapter, the research methodology, in the fourth chapter data analysis and the results gained due to the research have been dealt with and at the end the conclusion, research and management suggestions and suggestions for future researches as well as research restrictions will be provided.

\section{Literature Review}

\subsection{Service Quality}

Service quality is a customer's judgement about a product's overall excellence or superiority (Zeithaml, 1988) and is similar to an attitude (Parasuraman, Zeithaml \& Berry, 1985; Zeithaml, 1988). Parasuraman, Zeithaml, \& Berry (1988) developed a multiple-item scale, SERVQUAL, for measuring service quality and argued that service quality, as perceived by customers, originated from a comparison of customers' expectations and their perceptions of the performance delivered by the firm. Perceived service quality was viewed as "the degree and direction of discrepancy between consumers' perceptions and expectations" (Parasuraman et al., 1985). Collecting data from five service categories, Parasuraman et al. (1988) identified five dimensions of service quality:

1) Reliability (the ability of service firms to perform the promised service dependably and accurately);

2) Responsiveness (willingness to help customers and provide quick service);

3) Assurance (the knowledge and courtesy of a firm's employees and their ability to inspire trust and confidence)

4) Empathy (caring and personalized attention provided by the service firm); and

5) Tangibles (the physical facilities, equipment and appearance of a firm's employees).

Gronroos (1984) offered a service quality model with dimensions of technical quality (what consumer gets), functional quality (how consumer gets the service) and corporate image (how consumers perceive the firm and its services). Similarly, Lehtinen and Lehtinen (1991) offered another model with three dimensions of service quality: physical, interactive and corporate. Physical quality is about the quality of physical products involved in service delivery and consumption. Interactive dimension refers to the interaction between the customers and the service organization employees. Corporate quality refers to the corporate image as perceived by the customers. 


\subsection{Self-Service Technologies}

As it develops in sophistication, the use of technology is altering traditional business and marketing practices. Self-service technologies (SSTs) have a substantial impact on traditional methods of business and business strategies (Beatson, 2010). Self-service technologies are technological interfaces that allow consumers to serve themselves, independent of direct involvement with employees (Meuter, Ostrom, Roundtree, \& Bitner, 2000). Currently, self-service technologies can be found in various retail environments, such as banks (ATMs), airlines (self-service boarding pass dispensers), gas stations (self-service gasoline pumps), grocery stores (self-scan and pay systems), and hotels (automated check-in and check-out facilities), among others. High SST performance and successful marketing strategies can enhance consumers' in-store experiences, and, in turn, potentially increase store profits.

\subsubsection{Self-Service Technologies (SSTs) in Iranian Banking}

The trend of developing and expanding information technology (IT) throughout the world, especially in developed countries on the one hand, and commercial relationships between countries and nations on the other hand, have prompted Iranian banks to undertake widespread and extensive activities in line with applying computer systems in their banks in the 1980s and 1990s. Consequently, consumers' knowledge and awareness have been enhanced regarding automated banking operations by gradually expanding access to the internet and PCs. As a result, Iranian commercial banks consider self-service technologies (SSTs) in their future planning, along with improving their methods and moving toward modern banking, moving toward self-service technologies (SSTs) is an ambiguous and unstable step without creating its infrastructure. First self-service technologies (SSTs) will only be able to move and secure a stable position with an integrated and comprehensive software and hardware system. Activities and measures banks are making to prepare a comprehensive integrated automation plan indicate that banks have also realized the need to provide infrastructure with a comprehensive and integrated automation system. At present, creating an integrated, comprehensive automation plan is top of the banks' agenda in order to move toward developing modern banking. After implementing these plans, the banks will enjoy the readiness required for self-service technologies (SSTs) (Sadeghi and Heidarzadeh Hanzaee, 2010).

\subsection{Customer Satisfaction}

The degree of overall pleasure or contentment felt by the customer, resulting from the ability of the service provider to fulfill the customer's desire, expectations and needs in relation to the service. Customer satisfaction is a complex construct and has been defined in various ways (Ganguli \& Roy, 2011). Customer satisfaction is the sense of attitude and feeling of consumer toward a product or service after it has been used (Kassim \& Abdullah, 2010). Recently, researcheres have argued that there is a distinction between customer satisfaction as related to tangible products and as related to service experience. In service markets, customer satisfaction is often measured as the difference between service expectation and experience (Ganguli \& Roy, 2011). Rust and Oliver stated that satisfaction reflects whether a consumer believes that the possession and use of a service evokes positive feelings (Jamal \& Anastasiadou, 2009).

\subsection{Conceptual Framework and Research Hypotheses}

Figure 1 presents the conceptual model of customer satisfaction and suggests that:

1) Reliability, tangibility, empathy, responsiveness and assurance are related to customer satisfaction; and

2) Self-service technologies (SSTs) moderate the link between tangibles and customer satisfaction 


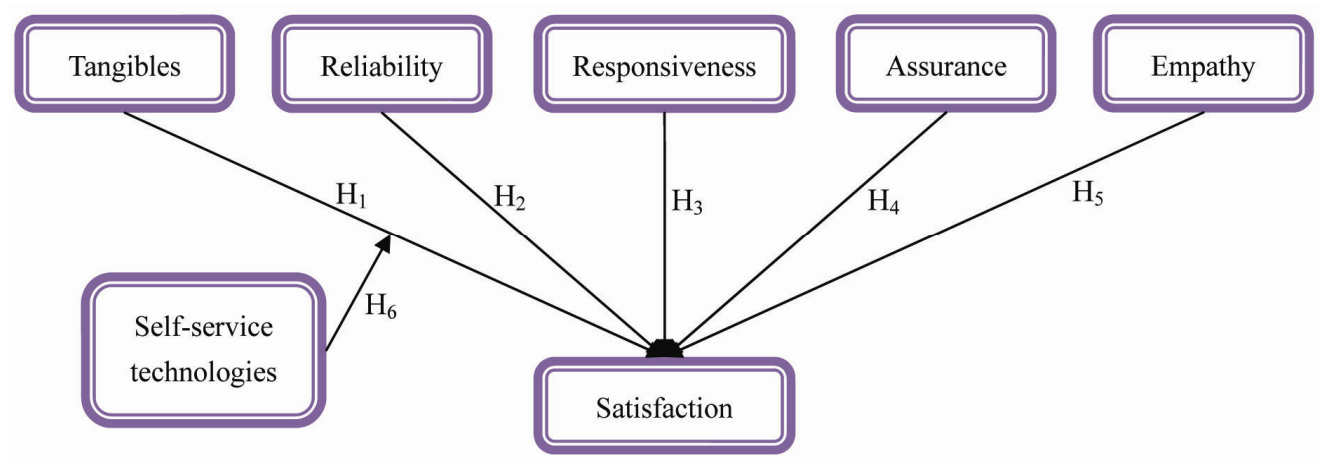

Figure 1. A conceptual model of satisfaction

Source: Parasuraman et al. (1988); Proenca \& Rodrigues (2011).

\subsubsection{Effects of Service Quality Dimensions on Customer Satisfaction}

Customer satisfaction is the full meeting of one's expectations and can be described as the feeling or attitude of a customer towards a product or service after it has been used (Evans, Jamal, \& Foxall, 2006). While a substantial amount of research has reported a causal link between service quality and customer satisfaction (Al-Hawari, Ward, \& Newby, 2009; Amin \& Isa, 2008; Ganguli \& Roy, 2010, 2011; Jamal \& Anastasiadou, 2009; Kassim \& Abdullah, 2010; Munteanu, Ceobanu, Bobalca, \& Anton, 2010; Saha \& Theingi, 2009; Santouridis \& Trivellas, 2010), few have investigated the link between each of the service quality dimensions and satisfaction and have reported some mixed results. For instance, Arasli, Mehtap-Smadi \& Katircioglu (2005) reported that assurance, reliability, empathy and tangibles dimensions of service quality were predictors of customer satisfaction in the Cyprus banking sector. Similarly, Yavas, Bilgin \& Shemwell (1997) found tangibles, empathy and responsiveness to be important predictors of customer satisfaction among bank customers in Turkey. Additional support comes from Zhou (2004), who reported that reliability and assurance were important predictors of satisfaction for bank customers in China. Moreover, Baumann, Burton, Elliot \& Kehr (2007) found that all dimensions except tangibility impacted the customer satisfaction of Australian banking customers. Furthermore, due to the intangible nature of services, it is often difficult for customers to understand and evaluate services (LeBlanc \& Nguyen, 1988; Legg \& Baker, 1996). Thus customers make inferences about the service quality on the basis of tangibles such as buildings, equipment, physical layout that surround the service environment (Bitner, 1990, 1992). This is supported by evidence from environmental psychology, which states that consumers form inferences about a focal object or person based on environmental cues (Baker, Grewal \& Parasuraman, 1994; Baker, Parasuraman, Grewal, \& Voss, 2002). Bitner (1990) reported that subjects developed attributions about service failures based on the physical environment of a travel agency. Also, Wakefield and Blodgett (1999) found that the tangible aspects of the service environment had a critical impact on customers' affective responses and their behavioural intentions involving a leisure service. These arguments confirm the significance of different dimensions of service quality to a varying degree and highlight the need for the research reported here. The following hypotheses are therefore proposed:

H1. As customer perceptions of tangibles dimension of service quality become more favourable, customers will feel more satisfied towards the service provider.

H2. As customer perceptions of reliability dimension of service quality become more favourable, customers will feel more satisfied towards the service provider.

H3. As customer perceptions of responsiveness dimension of service quality become more favourable, customers will feel more satisfied towards the service provider.

H4. As customer perceptions of assurance dimension of service quality become more favourable, customers will feel more satisfied towards the service provider.

H5. As customer perceptions of empathy dimension of service quality become more favourable, customers will feel more satisfied towards the service provider.

\subsubsection{Moderating Effects of Self-Service Technologies (SSTs)}

Several authors have examined the relationship between satisfaction and service quality, particularly when this is influenced by new technologies (Al-Hawari et al., 2009; Bitner, Ostrom, \& Meuter, 2002; Johns \& Perrott, 2008; 
LaBarbera \& Mazursky, 1983; Marr \& Prendergast, 1993; Meuter et al., 2000; Nilsson, 2007; Proenca \& Rodrigues, 2011; Shamdasani, Mukherjee, \& Malhotra, 2008). Meuter et al., (2000) showed that satisfaction with SSTs is mainly related to the capacity to customise the service; in addition, a secondary benefit that contributes to customer satisfaction is the convenience of being able to produce and consume services when and where customers need them. Mols (1998) reported that users of internet banking in Denmark were more satisfied and loyal to their banks than were non-users. Bitner et al. (2002) identified convenience and ease of access to services as benefits of SSTs that induce customer satisfaction, whereas malfunctioning hardware and software cause dissatisfaction. In a similar vein, Meuter et al. (2000) reported that technological malfunction that obliges consumers to use the conventional service is a significant cause of dissatisfaction. Proenca and Rodrigues (2011) examined the behavior Portuguese users and non-users of self-service technologies (SSTs) in banking services. They reported that users of self-service technologies (SSTs) were more satisfied to their banks than were non-users. Because SSTs provide enhanced accessibility and customization of services, it is likely that customers will be more satisfied (Bitner et al., 2002; Meuter et al., 2000). The following hypothesis is therefore proposed:

H6. Self-service technologies (SSTs) positively moderate the link between tangibles and customer satisfaction.

\section{Methodology}

\subsection{Research Method}

The research method used for this research in terms of objective has been applied, in terms of path has been descriptive (correlation), as for time cross-sectional and in terms of conducting or data gathering it has been done via questionnaires (field) and in terms of the in-depth level, it is wide range conducted as per the casual model and analysis of variance-covariance matrix (ANOVA-ANCOVA statistical testing).

\subsection{Location (Statistical Population) and Time of Research}

The statistic group for this research has been the customers of $<$ Ghavamin Bank $>$ in Khorasan-e Razavi, Khorasan-e Shomali and Khorasan-e Jonoobi provinces of Iran and a number of 510 individuals were chosen as sample. The concerned group (Banking services) has been selected as it has got the highest interaction with the customers. The initial studies and the period of conducting this research has been in a time span of 5 months starting from September 23, 2011 through February 19, 2012. The cross-sectional questionnaires belong to period Aril 3, 2012 through July 21, 2012.

\subsection{Sampling Method and Determining the Samples Size}

Considering the features of the current research, the sampling method applied for this research has been the probable type, conducted in two phases. In the first phase the simple random sampling has been used to choose the branches and in phase two the single- stage cluster sampling has been used in factor analysis; the data from the statistic group and the number of samples are of special significance. Generally, the strength or weaknesses of the factor analysis results have direct relation with the quantity of samples in that 2000 samples is very good, 400-500 is good and 300 samples is average and finally 100 samples is considered weak (Lee, 2007). Bringing into attention the time and the costs limits as well as the above introduction, the number of samples in all branches of Ghavamin Bank in the three provinces has been 510 items.

\subsection{Methods and Instruments Applied for Data Gathering}

Produce considering the fact that the procedures for conducting this research includes both quantitative \& qualitative parts, In each part it has been essential to utilize various means and methods ; that is the reason why semi-structured interview with customers and banking industry experts have been used in the qualitative part of the research. In the quantitative part of the research, the most significant means for data gathering has been the questionnaires. The questionnaires used for the research have been prepared with regard to the theoretical aspects and the results gained from the qualitative part procedures of the research and its objectives, variables and the information required for the hypothesis testing of the research. The first section of the questionnaire concerns the demographic information of the respondents and has got questions about the details of the respondents including age, sex, qualification, type of services received from the bank, and eventually the type of bank account. In the second section of the questionnaire, there were items relating to measuring each of the latent variables.

In devising questions for the main part of the questionnaire the Likert-type scale from 1-5 options which is of the ordinal scale types has been used and includes questions that respondent may as per his own discrete choose one of the five options provided as per the Likert-type scale ( 1 = "total disagreement"; 5 = "total agreement"). In order to measure the research structure the scales used by (Al-Hawari et al., 2009; Parasuraman et al., 1988; Proenca and Rodrigues, 2011) which have been utilized in devising some of the questions on the questionnaire. 


\subsubsection{Validity of the Measurement Instruments}

In order to verify the initial validity of the questionnaire, the content validity method, the opinions of university professors and the experts as well as standard questionnaires have been used. In the structural equations model (SEM) used for determining the validity confirmatory factor analysis (CFA) and average variance extracted (AVE) have been used for construct validity and discriminant validity respectively (Byrne, 2008) and in this research the said parameters have been used for validity determination of the questionnaires.

\subsubsection{Reliability of the Measurement Instruments}

The conventional method used for improving and evaluating the measurement scales is estimating the reliability using chronbach's coefficient alpha. The composite reliability method is used in the structural equations model in order to measure the reliability both of which have been used in order to determine the reliability of the constructs of this study (Byrne, 2008).

\subsection{Data Analysis and Interpretation}

In order to describe the data, the frequency distribution tables have been used in this research and at the data inference stage the structural equations models (SEM) have been used which deal with the analysis of variance-covariance matrix (ANOVA-ANCOVA statistical testing). For this reason, confirmatory factor analysis (CFA), path analysis using LISREL 8.54 \& SPSS 18.0 softwares have been used.

\subsubsection{Structural Equations Model}

To test this research study's model, we have used data analysis with the help of SEM. Modeling of structural equations means creating a statistical model for the study of linear relations between latent (unviewed) variables and evident (viewed or observed) variables. In other words, structural equation modeling is a powerful statistical tool that combines a measurement model (affirmative factor analysis) and the structural model (regression of path analysis) into one statistical synchronic test (Vermunt and Magidson, 2005).

\section{Analyses and Results}

\subsection{Descriptive Statistics}

The current statistics have been used to describe the demographic characteristics of the respondents and the status of the latent variables transmittal.

\subsubsection{Examining the Normal Status of Variables Distribution}

Table 1. The results of Skewness and Kurtosis test

\begin{tabular}{lcc}
\hline Latent Variables & $\chi^{2}$ & Significance \\
\hline Tangibles & 3.145 & 0.514 \\
Reliability & 1.648 & 0.328 \\
Responsiveness & 3.032 & 0.187 \\
Assurance & 3.681 & 0.135 \\
Empathy & 1.878 & 0.302 \\
Satisfaction & 1.850 & 0.309 \\
Self-service technologies & 3.032 & 0.193 \\
\hline
\end{tabular}

As presented in the above table, The Skrewness and Kurtosis test has been used In order to show that the latent variables of this research have got the normal status of distribution .In this test the null hypothesis is the normality of distribution. Since all levels of significance are above 0.05 therefore the null hypothesis indicating the distribution is normal has been accepted. So the normal conditions of the latent variables in question for the estimation of the unidentified parameters shall be reliable. 


\subsubsection{Demographic Characteristics of Respondents}

Table 2. Demographic characteristics and usage patterns of respondents

\begin{tabular}{|c|c|c|c|}
\hline Measure & Item & Frequency & Percentage \\
\hline \multirow[t]{2}{*}{ Sex } & Male & 381 & 74.7 \\
\hline & Female & 128 & 25.1 \\
\hline \multirow[t]{5}{*}{ Age } & $18-24$ & 28 & 5.5 \\
\hline & $25-34$ & 202 & 39.8 \\
\hline & $35-44$ & 141 & 27.8 \\
\hline & $45-54$ & 100 & 19.7 \\
\hline & $55-64$ & 26 & 5.1 \\
\hline \multirow[t]{9}{*}{ Qualifications } & Higher than 65 & 11 & 2.2 \\
\hline & Non-responded & 2 & 0.4 \\
\hline & Below high school certificate & 2 & 0.4 \\
\hline & High school certificate & 178 & 35 \\
\hline & Associate's degree & 116 & 22.8 \\
\hline & Bachelor's degree & 142 & 27.9 \\
\hline & Master's degree & 41 & 8.1 \\
\hline & $\mathrm{PhD} \&$ higher & 30 & 5.9 \\
\hline & Non-responded & 4 & 0.8 \\
\hline \multirow[t]{10}{*}{ Type of service used } & Telephone banking & 34 & 6.7 \\
\hline & SMS & 11 & 2.2 \\
\hline & ATMs & 50 & 9.8 \\
\hline & Internet banking & 2 & 0.4 \\
\hline & Electronic system services & 16 & 3.1 \\
\hline & Real facilities and interest free loans & 80 & 15.7 \\
\hline & Mehregan stocks & 13 & 2.5 \\
\hline & Habib fund & 8 & 1.6 \\
\hline & Naja services & 3 & 0.6 \\
\hline & The combination of services & 293 & 57.5 \\
\hline \multirow[t]{8}{*}{ Type of account } & Short-term & 62 & 12.2 \\
\hline & Long-term & 5 & 1 \\
\hline & Rabi'a scheme & 22 & 4.3 \\
\hline & Zarrin scheme & 149 & 29.2 \\
\hline & Payment on maturity date & 9 & 1.8 \\
\hline & Current account/Interest free & 9 & 1.8 \\
\hline & Savings account/Interest free & 16 & 3.1 \\
\hline & The combination of services & 238 & 46.7 \\
\hline
\end{tabular}

As shown in Table 2, Learning about the sample demographic characteristics is useful in that it helps the general characteristics of the group to be reviewed and its general characteristics be known to other scholars and they can be used to correlate the result to other communities, and or they could be used in designing the future researches for other communities.

\subsection{Inferential Statistics}

This statistics have been utilized for inference over the characteristics of the statics group. 


\subsubsection{Investigating Validity and Reliability of the Measurement Instrument of the Research}

Table 3 . The results of validity and reliability analysis

\begin{tabular}{lccc}
\hline Constructs & $\begin{array}{c}\text { AVE } \\
\text { (Acc. Value }>0.50)\end{array}$ & $\begin{array}{c}\text { Composite reliability } \\
\text { (Acc. Value }>0.70)\end{array}$ & $\begin{array}{c}\text { Cronbach's } \alpha(\text { Acc. } \\
\text { Value }>0.70)\end{array}$ \\
\hline Tangibles & 0.791 & 0.841 & 0.748 \\
Reliability & 0.637 & 0.788 & 0.865 \\
Responsiveness & 0.684 & 0.795 & 0.766 \\
Assurance & 0.748 & 0.821 & 0.724 \\
Empathy & 0.713 & 0.833 & 0.764 \\
Satisfaction & 0.725 & 0.845 & 0.805 \\
Self-service technologies & 0.757 & 0.861 & 0.798 \\
\hline
\end{tabular}

In the current research, in addition to the construct validity, other tests such as content validity and discriminant validity have been used to determine the validity of the measurement instrument. In general, in case the indexes making up a measurement instrument are based on the comprehensive investigation of specialized literature relating to the topic of the study, then we could be assured of the content validity. Also the questionnaire of this research has been designed based on investing and profound study of specialized research and applied literature and by gathering the customers, experts and scientific and executive opinions as for the coverage of their feedback and this can be considered a witness to the precise content validity. By discriminant validity the measurement validity of the research can be assessed as well and since the constructs studied in this research are of average variance extracted (AVE) above 0.5, therefore the research's questionnaire is valid. In order to examine the reliability the cronbach's coefficient alpha and composite reliability have been used. Reliability means that there should be the same understanding of the questions among the various respondents. In structural equations model quantities above 0.7 for each construct indicate of an appropriate reliability (Byrne, 2008). Since the constructs studied in this study have got both cronbach's coefficient alpha and composite reliability above 0.7 ; therefore, the questionnaire used for this research is reliable. The results for investigating the validity and reliability the measurement instrument of this research have been shown in table 3 . Considering this table it could be stated that with a $99 \%$ assurance that the questions used in the questionnaire for measuring the research constructs are of appropriate validity and reliability; therefore, the current research questionnaire is standard. Now designing for structural model for examining the causal relations and the relation between the research constructs could be done and by using the structural model the hypotheses of the research could be tested.

\subsubsection{Measurement Model for the Latent Variables of the Research (Confirmatory Factor Analysis)}

In the structural equations model, first the construct validity is to be studied to find out if the selected items (observed variables) have got the required precision for measuring the constructs (latent variables) needed, in so doing the confirmatory factor analysis is used In case the factor loading of each item and its construct with a $\mathrm{t}$-value is above 1.96, then that item has got the required precision for measurement (Byrne, 2008). Considering the root mean square error of approximation (RMSEA) for the first model is more than 0.08 ,so in order to use these constructs in designing of the structural model research and hypothesis testing is needed in order that some improvements takes place in the measurement model. As it is required in the methodology of structural equations model, the researcher should correct and improve the stages using the significance of chi-square $(\chi 2)$. for this reason, the D2 which judges from the reduction in chi-square and its significance difference, has been used and as far as the improved model causes significance difference due to chi-square compared to its previous stages the improvement of the model should be continued so that the estimated parameters in the final \& improved model turns statistically reliable and could be used for the adjustability of the items with the constructs of the study (Byrne, 2001). In the current research, the measurement model or the confirmatory factor analysis and the results have been shown in table 4 . The results which are the estimated parameters in the final improvement model signifies what the researcher has been trying to test via the questionnaire has been achieved through this instrument. The confirmation of the measurement model indicates that the relations between the latent and observed variables in the model are reliable. 
Table 4. The results of measurement model (CFA) for latent variables

\begin{tabular}{|c|c|c|c|c|}
\hline Constructs & Measurement Item & Factor Loadings & t-value & p-value \\
\hline \multirow[t]{4}{*}{ Tangibles } & $\mathrm{Q}_{3}$ & 0.76 & 19.38 & 0.01 \\
\hline & $\mathrm{Q}_{4}$ & 0.71 & 16.78 & 0.01 \\
\hline & $\mathrm{Q}_{5}$ & 0.75 & 19.26 & 0.01 \\
\hline & $\mathrm{Q}_{6}$ & 0.88 & 23.39 & 0.01 \\
\hline \multirow[t]{5}{*}{ Reliability } & $\mathrm{Q}_{7}$ & 0.72 & 18.43 & 0.01 \\
\hline & $\mathrm{Q}_{8}$ & 0.83 & 22.86 & 0.01 \\
\hline & $\mathrm{Q}_{9}$ & 0.79 & 20.86 & 0.01 \\
\hline & $\mathrm{Q}_{10}$ & 0.74 & 19.04 & 0.01 \\
\hline & $\mathrm{Q}_{11}$ & 0.75 & 19.16 & 0.01 \\
\hline \multirow[t]{4}{*}{ Responsiveness } & $\mathrm{Q}_{12}$ & 0.78 & 19.72 & 0.01 \\
\hline & $\mathrm{Q}_{13}$ & 0.71 & 18.25 & 0.01 \\
\hline & $\mathrm{Q}_{14}$ & 0.88 & 24.85 & 0.01 \\
\hline & $\mathrm{Q}_{15}$ & 0.89 & 25.35 & 0.01 \\
\hline \multirow[t]{4}{*}{ Assurance } & $\mathrm{Q}_{16}$ & 0.85 & 23.37 & 0.01 \\
\hline & $\mathrm{Q}_{17}$ & 0.80 & 21.36 & 0.01 \\
\hline & $\mathrm{Q}_{18}$ & 0.84 & 23.11 & 0.01 \\
\hline & $\mathrm{Q}_{19}$ & 0.82 & 22.05 & 0.01 \\
\hline \multirow[t]{5}{*}{ Empathy } & $\mathrm{Q}_{20}$ & 0.70 & 17.29 & 0.01 \\
\hline & $\mathrm{Q}_{21}$ & 0.68 & 16.73 & 0.01 \\
\hline & $\mathrm{Q}_{22}$ & 0.71 & 17.62 & 0.01 \\
\hline & $\mathrm{Q}_{23}$ & 0.75 & 18.92 & 0.01 \\
\hline & $\mathrm{Q}_{24}$ & 0.68 & 16.88 & 0.01 \\
\hline \multirow[t]{4}{*}{ Self-service technologies } & $\mathrm{Q}_{25}$ & 0.80 & 21.14 & 0.01 \\
\hline & $\mathrm{Q}_{26}$ & 0.91 & 25.57 & 0.01 \\
\hline & $\mathrm{Q}_{27}$ & 0.82 & 22.06 & 0.01 \\
\hline & $\mathrm{Q}_{28}$ & 0.77 & 19.90 & 0.01 \\
\hline \multirow[t]{3}{*}{ Satisfaction } & $\mathrm{Q}_{29}$ & 0.84 & 23.00 & 0.01 \\
\hline & $\mathrm{Q}_{30}$ & 0.89 & 24.89 & 0.01 \\
\hline & $\mathrm{Q}_{31}$ & 0.94 & 27.35 & 0.01 \\
\hline
\end{tabular}

4.2.2.1 Fit the Measurement Model for the Latent Variables of the Research

Table 5. The fitting indexes of measurement model for latent variables

\begin{tabular}{|c|c|c|c|}
\hline Constructs & Indexes & Accepted Values & Values \\
\hline \multirow[t]{9}{*}{ Independent variables } & $\chi^{2} / \mathrm{df}$ & Less Than Five & 4.22 \\
\hline & RMR & Close to zero & 0.16 \\
\hline & SRMR & Close to zero & 0.07 \\
\hline & GFI & $90 \%$ and above & 0.92 \\
\hline & NFI & $90 \%$ and above & 0.97 \\
\hline & NNFI & $90 \%$ and above & 0.97 \\
\hline & IFI & $90 \%$ and above & 0.97 \\
\hline & CFI & $90 \%$ and above & 0.97 \\
\hline & RMSEA & $0.080 \%$ and less & 0.080 \\
\hline \multirow[t]{9}{*}{ Dependent variables } & $\chi^{2} / \mathrm{df}$ & Less than five & 0.00 \\
\hline & RMR & Close to zero & 0.18 \\
\hline & SRMR & Close to zero & 0.10 \\
\hline & GFI & $90 \%$ and above & 0.91 \\
\hline & NFI & $90 \%$ and above & 0.95 \\
\hline & NNFI & $90 \%$ and above & 0.95 \\
\hline & IFI & $90 \%$ and above & 0.95 \\
\hline & CFI & $90 \%$ and above & 0.95 \\
\hline & RMSEA & $0.080 \%$ and less & 0.001 \\
\hline \multirow[t]{9}{*}{ Moderator variables } & $\chi^{2} / \mathrm{df}$ & Less than five & 2.20 \\
\hline & RMR & Close to zero & 0.18 \\
\hline & SRMR & Close to zero & 0.10 \\
\hline & GFI & $90 \%$ and above & 0.91 \\
\hline & NFI & $90 \%$ and above & 0.95 \\
\hline & NNFI & $90 \%$ and above & 0.95 \\
\hline & IFI & $90 \%$ and above & 0.95 \\
\hline & CFI & $90 \%$ and above & 0.95 \\
\hline & RMSEA & $0.080 \%$ and less & 0.049 \\
\hline
\end{tabular}


In order to assess the measurement model there are several fit indexes. In the current research the following indexed have been used: $\chi 2 / \mathrm{df}$, RMR, SRMR, GFI, NFI, NNFI, IFI, CFI and the valuable index RMSEA for evaluating the measurement model and the latent variables and the result have been shown in table 5 , all the fit indexes of the table have achieved the required quantity. Therefore the data of this research has got a suitable fit with the factor construct and the research foundation signifying the correspondence of the questions with the theoretic constructs and the results gained from the data correspond with the above model.

\subsubsection{Power Analysis of the Measurement Model for Latent Variables of the Research}

In order to assess the power of the measurement model for latent variables with regard to the small size of samples the power analysis method has been used in this research and the results indicate that in the present size and based on the quantities estimated the complete quantity of one has been achieved, so the measurement model of the latent variables of the research are reliable and the findings are interpretable. The power analysis diagram of measurement model for the latent variables of the research has been shown in figure 2 .

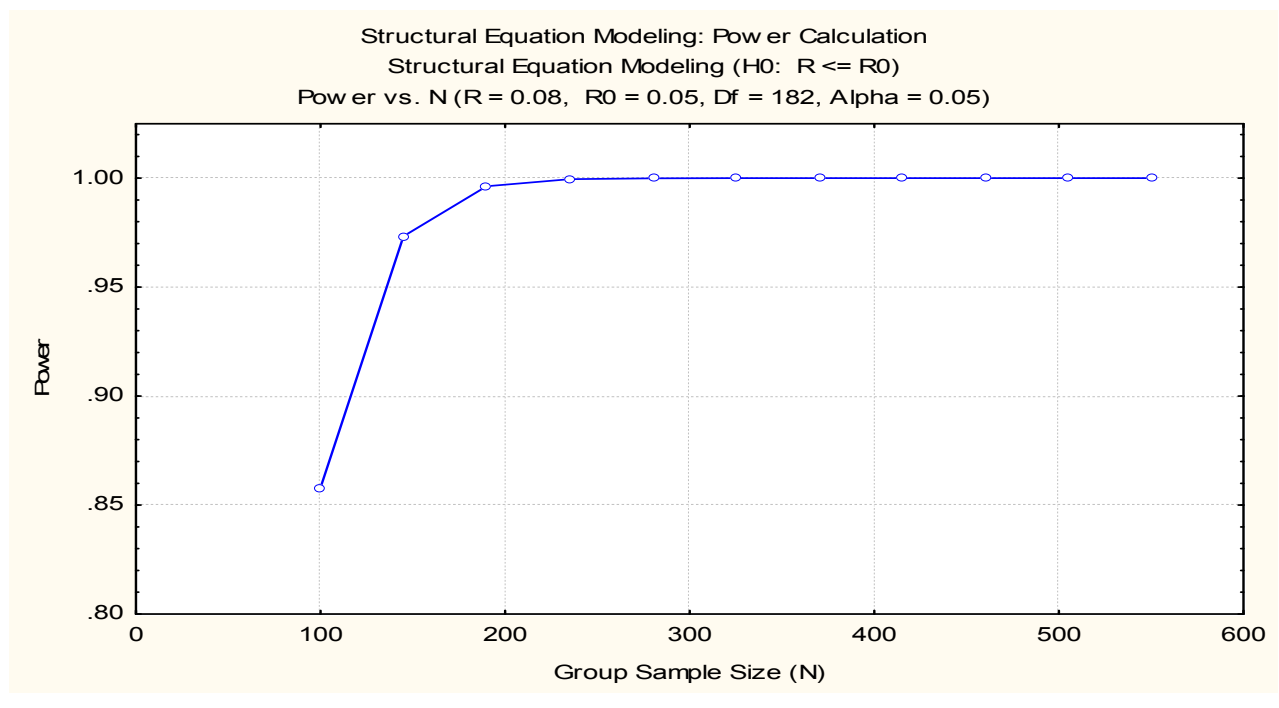

Figure 2. The power analysis diagram of measurement model for latent variables

\subsubsection{Structural Model (Path Analysis Model) of the Research}

Table 6. The results of path estimates for structural model

\begin{tabular}{lccc}
\hline Hypothesized path & Path coefficient & t-value & Result \\
\hline $\mathrm{H}_{1}$. Tangibles $\longrightarrow$ Satisfaction & 0.15 & 3.07 & Supported \\
$\mathrm{H}_{2}$. Reliability $\rightarrow$ Satisfaction & 0.06 & 0.51 & Rejected \\
$\mathrm{H}_{3}$. Responsiveness $\rightarrow$ Satisfaction & 0.26 & 2.08 & Supported \\
$\mathrm{H}_{4}$. Assurance $\longrightarrow$ Satisfaction & 0.42 & 3.40 & Supported \\
$\mathrm{H}_{5}$. Empathy $\longrightarrow$ Satisfaction & 0.20 & 1.38 & Rejected \\
$\mathrm{H}_{6}$ Self-service technologies $\longrightarrow$ Relationship Between tangibles and & 0.57 & 6.09 & Supported \\
satisfaction & & & \\
\hline
\end{tabular}

Notes: Significance of path coefficients: $\mathrm{p}<0.01$. 


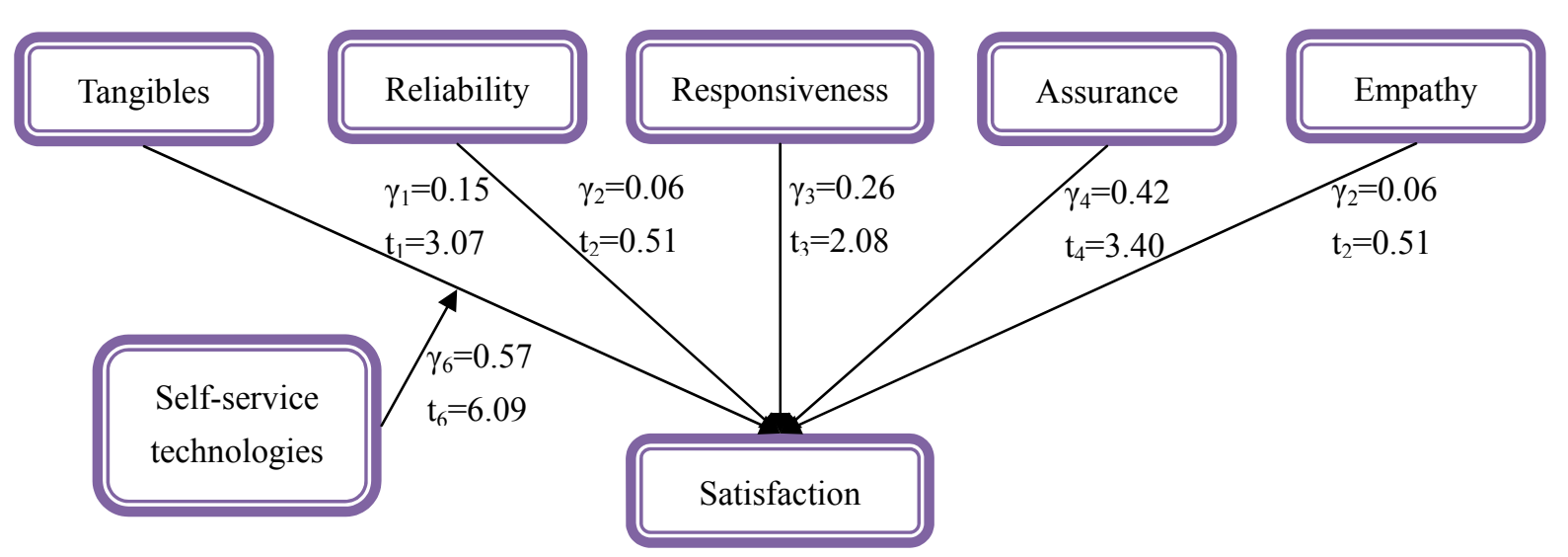

Figure 3. Path analysis model with results

Notes: Significance of path coefficients: $\mathrm{p}<0.01$.

After the verification of measurement model of the research, we can study the test for the relations between the latent variables of the research. Considering the fact that the second root mean square error of approximation (RMSEA) for the structural model used for the research has been reported above 0.1 ; as a result, for estimation precise estimation of the path coefficients of the hypotheses testing requires some corrections, so for this reason the D2 test which judges based on the decrease in chi-square $\left(\chi^{2}\right)$ and its significance has been used. In the correction part of LISREL model of this research, from restriction diagnosis of restrictions and adding additional parameters has been used in a way that among the available indexes in the model and with regard to LISREL output among some of them the covariance error was freed and by controlling it, the quantity improved.

As far as the corrected model causes a meaningful difference due to chi-square $\left(\chi^{2}\right)$, the model, correction should be continue model used for this research so that the estimated parameters in the final estimated model becomes reliable statistically and to use them for the hypothesis testing of the research. The data gained from the structural model of the research has been shown in table 6 and figure 3.

\subsubsection{Fit the Structural Model of the Research}

Table 7. The fitting indexes of structural model for this research

\begin{tabular}{llc}
\hline Indexes & Accepted values & Values \\
\hline$\chi^{2} / \mathrm{df}$ & Less than five & 4.05 \\
RMR & Close to zero & 0.17 \\
SRMR & Close to zero & 0.07 \\
GFI & $90 \%$ and above & 0.90 \\
NFI & $90 \%$ and above & 0.94 \\
NNFI & $90 \%$ and above & 0.93 \\
IFI & $90 \%$ and above & 0.94 \\
CFI & $90 \%$ and above & 0.94 \\
RMSEA & $80 \%$ and less & 0.077 \\
\hline
\end{tabular}

In the current research, different indexes have been used to assess the structural model of the research the results of which have been shown in table 7. All the fitting indexes of the table have gained a reasonable quantity. Therefore, the data of this research has got a proper fit with factor structure and underlying theory of the research indicating the validity of the findings of the research due to the structural model. Therefore, hypothesis testing of the research has got an acceptable precision.

\subsubsection{Power Analysis of the Structural Model of the Research}

In the current research in order to assess the structural model power, considering the sample size of the study, the power analysis has been used and the results indicate that in the current size and based on the quantity estimated, the complete quantity of one has been gained. Therefore, the power coefficient has been effective and the findings resulted from the structural model of the research are reliable and interpretable. The diagram of 
structural model power analysis has been shown in figure 4 .

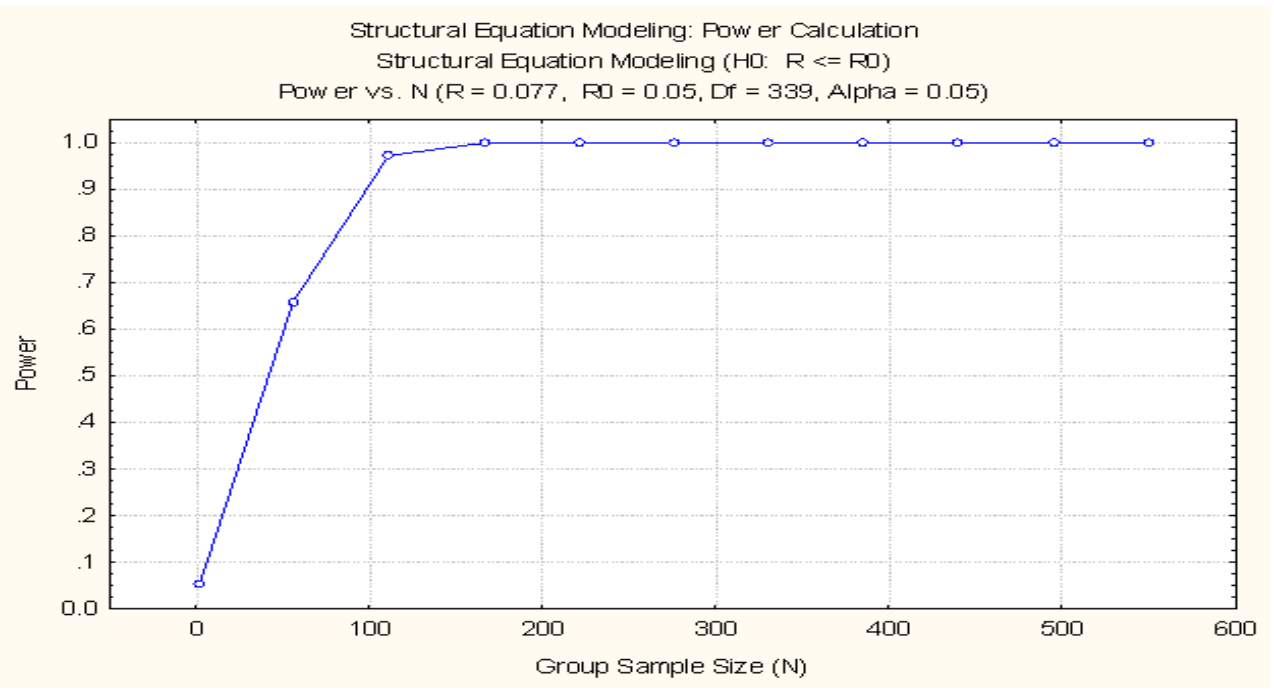

Figure 4. The power analysis diagram of structural model for this research

\subsection{The Results of Hypotheses Testing}

The first hypothesis (As customer perceptions of tangibles dimension of service quality become more favourable, customers will feel more satisfied towards the service provider) was supported. As shown in Figure 3 and Table $\mathrm{V}$, the path coefficient for this relationship was significant $\left(\gamma_{1}=0.15\right.$, $t$-value $=3.07$ ). The second hypothesis (As customer perceptions of reliability dimension of service quality become more favourable, customers will feel more satisfied towards the service provider) was rejected. As shown in Figure 3 and Table V, the path coefficient for this relationship was significant $\left(\gamma_{2}=0.06\right.$, $t$-value $\left.=0.51\right)$. The third hypothesis (As customer perceptions of responsiveness dimension of service quality become more favourable, customers will feel more satisfied towards the service provider) was supported. As shown in Figure 3 and Table V, the path for this relationship was significant $\left(\gamma_{3}=0.26\right.$, $\mathrm{t}$-value $\left.=2.08\right)$. The fourth hypothesis (As customer perceptions of assurance dimension of service quality become more favourable, customers will feel more satisfied towards the service provider) was supported. As shown in Figure 3 and Table V, the path coefficient for this relationship was significant $\left(\gamma_{4}=0.42\right.$, $\mathrm{t}$-value $=3.40$ ). The fifth hypothesis (As customer perceptions of empathy dimension of service quality become more favourable, customers will feel more satisfied towards the service provider) was rejected. As shown in Figure 3 and Table $\mathrm{V}$, the path coefficient for this relationship was significant $\left(\gamma_{5}=0.20\right.$, $\mathrm{t}$-value $\left.=1.38\right)$.

In the model of this research a moderator variable (self-service technologies) on the physical and tangibles link and customer satisfaction has been studied. For this reason the subgroup method has been used. In this method, the researcher first should examine the impact of the independent variable on the dependent variable in two sets which are available for the moderator variable. Considering the mean of the sample, the moderator levels should be divided in two upper and lower ones and the structural model should be used for both levels. Therefore, in such case providing a single model shall not be a proper method (Byrne, 2001).the results proved that the path coefficients of the impact of the tangibles on the customers satisfaction has been calculated in the upper level of self-service technologies moderator variable as 0.76 and in lower levels of self-service technologies variables as 0.19 .

As shown in Figure 3 and Table V, the path for the relationship between tangibles and customer satisfaction was significant $\left(\gamma_{6}=0.57\right.$, t-value $\left.=6.09\right)$. Thus, the sixth hypothesis (Self-service technologies positively moderate the link between tangibles and customer satisfaction) was supported.

Therefore, considering the results gained from the research it could be stated that the individuals in the upper levels of satisfaction from the self-service technologies had the perceived the impact of the tangibles on the customers' satisfaction more than the direct effect of the tangibles on the customers' satisfaction compared to those who were in a lower level of satisfaction from the self-service technologies. In other words, the more satisfactory the quality of the self-service technologies in bank branches, the more impact of the tangibles on the 
satisfaction of the customers is witnessed. The structural equation extracted from the model is as follows:

Satisfaction $=0.15 *$ tangibles $+0.26 *$ responsiveness $+0.42 *$ assurance $+0.57 *$ self-service technologies, Errorvar $=0.20, \mathrm{R}^{2}=0.80$

These findings prove that 80 percent of the changes of the dependent variable of the customers' satisfaction in the bank branches of this study are from the independent variables, tangibles, responsiveness, assurance and the impact of the self-services technologies moderators and 20 percent of the changes are resulted from other variables of the research. As a result, the results of this research indicate that the factors studied by the researcher indicate a customers' satisfaction of 80 percent, which is a quite remarkable figure.

\section{Conclusions, Implications, Limitations and Future Research Directions}

\subsection{Main Conclusions}

Some of the existing restrictions are in a way that conducting some supplementary researches will meet them. In this way we could provide some research suggestions with regard to them. The essence of this study has maneuvered some new research findings which have been dealt with in this part.

\subsubsection{Suggestions Concerning the Tangibles}

1) Providing enough proper space and facilities for the convenience of the customers, especially when there is a crowd of customers.

2) Using signs and special boards in order to direct the customers in a better way.

3) Nice and attractive interior design.

4) Providing comforting equipments for the customers waiting for their turns.

5) Using more sign boards inside the branch to direct the visitors.

6) The order of documents as well as the procedures and service providing via a specific board to affix all the notices on for the customers' information.

7) Paying attention to the appearance of the staff and using smart uniforms.

\subsubsection{Reliability Suggestions}

1) Banks should pave the way for providing service to the customers by providing their staff with proper training as well as rendering sufficient information to the customers and precise drawing of the service providing procedure.

2) The staff should be appreciated and promoted so that where there is some obstacles in the customers' affairs, they cooperate to remove these issues.

3) It is advised that the authorities put fulfillment of obligations their priority and they should announce providing of new services to customers once they are sure of being able to do so.

4) Management information systems experts should be consulted In order to create a reliable situation regarding the manner of providing the customers with information.

\subsubsection{Suggestions Concerning Responsibility and Responsiveness}

1) It is advised the materialistic and spiritual incentives to be used in order to promote the motivations of the staff to take care of the customers and to assist them.

2) For the sake of the customers' information, it would better to provide the staff's job description, position and details posted on a table stand and/or by using other methods.

\subsubsection{Suggestions Concerning Assurance}

1) It is suggested that banks offer some educational workshops to upgrade their staff knowledge .It's emphasized that such workshops should include the latest issues, principals, regulations and specialized rules.

2) It is advised that some courses be offered for the staff regarding specialized courses in teaching the relations with the customers in order to minimize the weaknesses in this field.

3) For the customers' peace of mind, it would be better to arrange for them to have access to the respective directors whenever necessary.

\subsubsection{Suggestions Concerning Empathy}

1) In order to prevent from the waiting of the customers for long time, it is advised that the working hours and 
the number of the staff be revised and if needed, the staff should operate as per a schedule.

2) It is essential for the staff to consider the needs and issues of each customer separately and in so doing they should have the logical powers and proper incentives should be decided for this purpose.

3) The best time to offer services to customers should be checked via questionnaires.

4) The procedures for taking care of the customers' complaints via the voice of customer's system and the management should be expedited.

\subsubsection{Suggestions for Self-Service Technologies}

Considering the significance of self-services technologies, it is required that by effective educating, the bank branches get equipped with such facilities.

\subsection{Managerial Implications}

The researches on the literature topics and paying attention to service quality models signify that the key sections of the management as well as the service quality development could be summarized as follows:

- clear market and customer focus;

- motivated staff;

- clear understanding of concepts of service quality and factors affecting the same;

- effective implementation, measurement and feedback system;

- efficient customer care system;

- effective, problem-free availability of the electronic channels; and

- clear understanding of concepts of self-service technologies in banking services.

\subsection{Limitations}

Any research and study faces certain limitations or even problems (from the planning to implantation).In this research the following limitations also could be discussed:

1) The statistic group includes 40 private bank branches of Ghavamin. Irrespective of communications and extensive follow ups, at times distributing the questionnaires at the branches of some of the banks was not possible.

2) To assess the service quality, one of the requirements is that the customers spend some time on them after they are done, yet the customers did not show much interest to spend some time after they had received the services they required.

\subsection{Future Research Directions}

1) Providing a service quality improvement pattern focusing on the role of self-service technologies using the structural equations modeling.

2) Providing a service quality improvement implementation in private banks using a theory based on the data (GT).

3) SWOT analysis of service quality formation in private banks.

4) Designing systems with high reliability in order to provide service by private banks in Iran.

5) Designing a special banking model based on the self-service technologies in private banks.

6) Designing models for assessing the service quality of commercial banks at the level of substantial customers.

7) Examining and analyzing the service quality focusing on the self-service technologies role in other cultural fields from international to national and or the diverse minor cultures.

8) Designing service quality models focusing on the self-services technologies role in other service industries in Iran such as hotel-keeping, air travels, insurances, hospital services, educational, ... .

9) Checking the possibility of using the services quality models emphasizing on the role of self-services technologies in smaller towns and rural areas considering the existing differences in their social and economic status in comparison with the people living in metropolitans.

10) Assessing the services quality with sample private and government banks concentrating the role of the self-services technologies. 
11) Conducting this same research for Ghavamin Bank in other provinces and comparing the findings of the two researches together.

12) Applied study of service quality provided to the customers using the self-services technology \& the customers using the old systems of the banks.

\section{References}

Al-Hawari, M., Ward, T., \& Newby, L. (2009). The relationship between service quality and retention within the automated and traditional contexts of retail banking. Journal of Service Management, 20(4), 455-72. http://dx.doi.org/10.1108/09564230910978539

Amin, M., \& Isa, Z. (2008). An examination of the relationship between service quality perception and customer satisfaction. International Journal of Islamic and Middle Eastern Finance and Management, 1(3), 191-209. http://dx.doi.org/10.1108/17538390810901131

Anderson, E. A., \& Sullivan, M. W. (1993). The antecedents and consequences of customer satisfaction for firms. Marketing Science, 12, 125-44. http://dx.doi.org/10.1287/mksc.12.2.125

Arasli, H., Mehtap-Smadi, S., \& Katircioglu, S. T. (2005). Customer service quality in the Greek Cypriot banking industry. Managing Service Quality, 15(1), 41-7. http://dx.doi.org/10.1108/09604520510575254

Baker, J., Grewal, D., \& Parasuraman, A. (1994). The influence of store environment on quality inferences and store image. Journal of the Academy of Marketing Science, 22(4), 328-39. http://dx.doi.org/10.1177/0092070394224002

Baker, J., Parasuraman, A., Grewal, D., \& Voss, G. B. (2002). The influence of multiple store environment cues on perceived merchandise value and patronage intentions. Journal of Marketing, 66, 120-41. http://dx.doi.org/10.1509/jmkg.66.2.120.18470

Baumann, C., Burton, S., Elliot, G., \& Kehr, H. M. (2007). Prediction of attitude and behavioural intentions in retail banking. The International Journal of Bank Marketing, 25(2), 102. http://dx.doi.org/10.1108/02652320710728438

Beatson, A. (2010). Self-service technology and the moderating effects of consumer characteristics. International Journal of Services Technology \& Management, 14(2/3), 1-52. http://dx.doi.org/10.1504/IJSTM.2010.034333

Bitner, M. J. (1990). Evaluating service encounters: the effects of physical surroundings and employee responses. Journal of Marketing, 54(2), 69-83.

Bitner, M. J. (1992). Servicescapes: the impact of physical surroundings on customers and employees. Journal of Marketing, 56, 57-71.

Bitner, M., Brown, S., \& Meuter, M. (2000). Technology infusion in services encounters. Journal of Marketing Science, 28(1), 138-49. http://dx.doi.org/10.1177/0092070300281013

Bitner, M., Ostrom, A., \& Meuter, M. (2002). Implementing successful self-service technologies. Academy of Management Executive, 16(4), 96-109.

Bolton, R. N., \& Drew, J. H. (1991). A multistage model of customers' assessments service quality and value. Journal of Consumer Research, 17, 375-84.

Byrne, B. M. (2001). Structural Equation Modeling with AMOS: Basic Concepts, Applications and Programming. Mahwah, NJ: Lawrence Erlbaum Associates.

Byrne, B. M. (2008). Structural Equation Modeling, Multivariate applications series (1st ed.). London: Lawrence Erlbaum Associates Publication.

Cronin, J. J. Jr., \& Taylor, A. S. (1992). Measuring service quality: a re-examination and extension. Journal of Marketing, 56, 55-68.

Evans, M., Jamal, A., \& Foxall, G. (2006). Consumer Behaviour. London: Wiley.

Ganguli, S., \& Roy, S. K. (2010). Service quality dimensions of hybrid services, Managing Service Quality, 20(5), 404-24. http://dx.doi.org/10.1108/09604521011073713

Ganguli, S., \& Roy, S. K. (2011). Generic technology-based service quality dimensions in banking. International Journal of Bank Marketing, 29(2), 168-89. http://dx.doi.org/10.1108/02652321111107648

Gronroos, C. (1984). A service quality model and its marketing implications. European Journal of Marketing, 
18(4), 36-44. http://dx.doi.org/10.1108/EUM0000000004784

Gronroos, C. (1990). Service Management and Marketing: Managing the Moments of Truth in Service Competition. Lexington, MA: Lexington Books.

Ho, S.-H., \& Ko, Y.-Y. (2008). Effects of self-service technology on customer value and customer readiness. Internet Research, 18(4), 427-46. http://dx.doi.org/10.1108/10662240810897826

Jamal, A., \& Anastasiadou, K. (2009). Investigating the effects of service quality dimensions and expertise on loyalty. European Journal of Marketing, 43(3/4), 398-420. http://dx.doi.org/10.1108/03090560910935497

Johns, R., \& Perrott, B. (2008). The impact of internet banking on business-customer relationships (Are you being self-served? International Journal of Bank Marketing, 26(7), 465-82. http://dx.doi.org/10.1108/02652320810913846

Kassim, N., \& Abdullah, N. A. (2010). The effect of perceived service quality dimensions on customer satisfaction, trust, \& loyalty in e-commerce settings. Asia Pacific Journal of Marketing and Logistics, 22(3), 351-71. http://dx.doi.org/10.1108/13555851011062269

LaBarbera, P., \& Mazursky, D. (1983). A Longitudinal assessment of consumer satisfaction/dissatisfaction: the dynamic aspect of the cognitive process. Journal of Marketing Research, 20(4), 393-404. http://dx.doi.org/10.2307/3151443

LeBlanc, G., \& Nguyen, N. (1988). Customerrs' perceptions of service quality in financial institutions. The International Journal of Bank Marketing, 6(4), 7-18. http://dx.doi.org/10.1108/eb010834

Lee, S. Y. (2007). Structural equation modeling: A Bayesian approach. Chichester, UK: John Wiley and Sons.

Legg, D., \& Baker, J. (1996). Advertising strategies for service firms. In Lovelock, C. H. (Ed.), Services Marketing (3rd ed.). Englewood Cliffs, NJ: Prentice-Hall.

Lehtinen, U., \& Lehtinen, J. R. (1991). Two approaches to service quality dimensions. The Service Industries Journal, 11(3), 287-303. http://dx.doi.org/10.1080/02642069100000047

Marr, N. E., \& Prendergast, G. P. (1993). Consumer adoption of self-service technologies in retail banking, International Journal of Bank Marketing, 11(1), 3-10. http://dx.doi.org/10.1108/02652329310023381

Meuter, M., Ostrom, A., Roundtree, R., \& Bitner, M. (2000). Self-service technologies: understanding customer satisfaction with technology-based service encounters. Journal of Marketing, 64, 50-64. http://dx.doi.org/10.1509/jmkg.64.3.50.18024

Mols, P. (1998). The behavioral consequences of PC banking. International Journal of Bank Marketing, 16(5), 195-201. http://dx.doi.org/10.1108/02652329810228190

Munteanu, C., Ceobanu, C., Bobalca, C., \& Anton, O. (2010). An analysis of customer satisfaction in a higher education context. International Journal of Public Sector Management, 23(2), 124-40. http://dx.doi.org/10.1108/09513551011022483

Murphy, K. R., Myors, B., \& Wolach, A. (2008). Statistical power analysis: A simple and general model for traditional and modern hypothesis tests (3rd ed.). Hillsdale, NJ: Lawrence Erlbaum.

Parasuraman, A., Zeithaml, V. A., \& Berry, L. L. (1985). Aconceptual model of service quality and its implications for future research. Journal of Marketing, 49, 41-50. http://dx.doi.org/10.2307/1251430

Parasuraman, A., Zeithaml, V. A., \& Berry, L. L. (1988). SERVQUAL: a multi-item scale for measuring consumer perceptions of service quality. Journal of Retailing, 64(1), 12-40.

Proenca, J. F., \& Rodrigues, M. A. (2011). A comparison of users and non-users of banking self-service technology in Portugal. Managing Service Quality, 21(2), 192-210. http://dx.doi.org/10.1108/09604521111113465

Sadeghi, T., \& Heidarzadeh Hanzaee, K. (2010). Customer satisfaction factors (CSFs) with online banking services in an Islamic country I.R. Iran. Journal of Islamic Marketing, 1(3), 249-67. http://dx.doi.org/10.1108/17590831011082428

Saha, G. C., \& Theingi. (2009). Service quality, satisfaction, and behavioural intentions. Managing Service Quality, 19(3), 350-72. http://dx.doi.org/10.1108/09604520910955348

Sangeetha, J., \& Mahalingam, S. (2011). Service quality models in banking: a review. International Journal of Islamic and Middle Eastern Finance and Management, 4(1), 83-103. 
http://dx.doi.org/10.1108/17538391111122221

Santouridis, L., \& Trivellas, P. (2010). Investigating the impact of service quality and customer satisfaction on customer loyalty in mobile telephony in Greece. The TQM Journal, 22(3), 330-43. http://dx.doi.org/10.1108/17542731011035550

Schneider, B., \& White, S. (2004). Service Quality: Research Perspective. UK, London: SAGE Publications Ltd.

Shamdasani, P., Mukherjee, A., \& Malhotra, N. (2008). Antecedents and consequences of service quality in consumer evaluation of self-service internet technologies. The Service Industries Journal, 28(1), 117-38. http://dx.doi.org/10.1080/02642060701725669

Tsoukatos, E., \& Mastrojianni, E. (2010). Key determinants of service quality in retail banking. EuroMed Journal of Business, 5(1), 85-100. http://dx.doi.org/10.1108/14502191011043170

Vermunt, J. K., \& Magidson, J. (2005). Structural equation models: Mixture models. In B. Everitt \& D. Howell (Eds.), Encyclopedia of statistics in behavioral science (pp. 1922-27). Chichester, UK: John Wiley and Sons.

Wakefield, K. L., \& Blodgett, J. G. (1999). Customer response to intangible and tangible service factors, $\begin{array}{lllll}\text { Psychology } \quad \text { M } & \text { Marketing, }\end{array}$ http://dx.doi.org/10.1002/(SICI)1520-6793(199901)16:1<51::AID-MAR4>3.0.CO;2-0

Wessels, L., \& Drennan, J. (2010). An investigation of consumer acceptance of M-banking. International Journal of Bank Marketing, 28(7), 547-68. http://dx.doi.org/10.1108/02652321011085194

Woodside, A. G., Lisa, L. F., \& Robert, T. D. (1989). Linking service quality, customer satisfaction, and behavioural intentions. Journal of Health Care Marketing, 9, 5-17.

Yavas, U., Bilgin, Z., \& Shemwell, D. J. (1997). Service quality in the banking sector in an emerging economy: a consumer survey. International Journal of Bank Marketing, 15(6), 217-23. http://dx.doi.org/10.1108/02652329710184442

Zeithaml, V. A. (1988). Consumer perceptions of price, quality and value: a means-end model and synthesis of evidence. Journal of Marketing, 52(3), 2-22. http://dx.doi.org/10.2307/1251446

Zhou, L. (2004). A dimension-specific analysis of performance-only measurement of service quality and satisfaction in China's retail banking. The Journal of Services Marketing, 18(6/7), 534-546. http://dx.doi.org/10.1108/08876040410561866

\section{Appendix}

Assurance

1) The behavior of employees in the bank instills confidence in you.

2) You feel safe and secure in your transactions with the bank.

3) Employees in the bank have knowledge to answer your questions.

4) Employees in the bank are consistently courteous to you.

Empathy

1) Employees in the bank deal with you in a caring fashion.

2) The bank has personnel who give you individual attention.

3) The bank has your best interest at heart.

4) Employees at the bank understand your specific needs.

5) The bank has business hours convenient to you.

Self-service technologies (SSTs)

1) Application of service technology and mechanization for example network connection of the branches or diversity of self-service technologies such as (ATMs, internet banking, telephone banking) is for rendering better service to customers.

2) Available self-service technologies could be applied in all branches of this bank.

3) The quality of self-service technologies is desirable and safe. 
4) There is an appropriate relation with electronic services of the other branches of this bank in cities and other banks.

\section{Satisfaction}

1) I am fully satisfied with the provided service due to diversity of financial services of this bank.

2) I would like to receive service from this bank.

3) The service of this bank due to its quality is recommended to others.

\section{Copyrights}

Copyright for this article is retained by the author(s), with first publication rights granted to the journal.

This is an open-access article distributed under the terms and conditions of the Creative Commons Attribution license (http://creativecommons.org/licenses/by/3.0/). 